\title{
Differences in the expression of cytochromes P450 17a-hydroxylase and aromatase in Meishan and Yorkshire conceptuses at days 10.5-14.0 of gestation
}

\author{
M. A. Kaminski ${ }^{1 *}$, S. P. Ford ${ }^{2}$ and A. J. Conley ${ }^{3 \dagger}$ \\ ${ }^{I}$ Department of Animal and Range Sciences, North Dakota State University, Fargo, ND 58105, USA; \\ ${ }^{2}$ Department of Animal Science, Iowa State University, Ames, IA 50011, USA; and ${ }^{3}$ Department of \\ Population Health and Reproduction, College of Veterinary Medicine, University of California, Davis,
} CA 95616, USA

\begin{abstract}
The expression of cytochromes P450 17 $\alpha$-hydroxylase (P450c17) and aromatase (P450arom) was compared between preimplantation Chinese Meishan and domestic Yorkshire conceptuses during the period encompassing maternal recognition of pregnancy. Individual conceptuses were recovered on days 10.5, 11.0, 11.5, 12.0, and 14.0 of gestation. Diameter (spherical blastocysts), length (elongated blastocysts), DNA, protein and oestradiol content, as well as the amounts of P450c17 and P450arom (western analysis) were determined in individual conceptuses. Comparisons were made only between conceptuses of similar diameters on each day which restricted analyses to blastocysts $6 \mathrm{~mm}$ or less in diameter on days 10.5-12.0. Nonetheless, both DNA and protein content were greater in Yorkshire than in Meishan conceptuses. Oestradiol content also tended to be greater in Yorkshire than in Meishan conceptuses across days. A significant effect of breed and breed by day interaction was detected for P450c17. Expression of P450c17 in Yorkshire conceptuses increased markedly above that in Meishan conceptuses by day 11, remained high until day 11.5 and returned to values similar to those of Meishans by day 12. The expression of P450arom was also greater in Yorkshire than in Meishan conceptuses, but no breed by day interaction was detected. These data suggest that differences in development between Meishan and Yorkshire conceptuses include trophoblastic differentiation during preattachment stages. The significance and impact of this divergence in development on subsequent growth and survival remains to be determined.
\end{abstract}

\section{Introduction}

Embryo survival is an important determinant of litter size that potentially limits the efficiency of pig production. Unfortunately, relatively little is known about the factors that influence survival of pig embryos during the early preattachment stages of development. Chinese Meishan pigs have been viewed with interest in this regard because of their unusually large litter size (Cheng, 1983; Bolet et al., 1986; Haley et al., 1990) that may result from decreases in embryo mortality (Bazer et al., 1988). Certainly, recent studies on Meishan and Yorkshire embryos support the notion that there are marked developmental differences between these breeds. It has been shown both in vitro (Youngs et al., 1993) and in vivo (Anderson et al., 1993) that Meishan conceptuses at the same day of gestation have a smaller diameter and contain less total oestradiol and DNA

\footnotetext{
*Present address: Department of Cell Biology, Neurobiology, and Anatomy College of Medicine, University of Cincinnati, PO Box 670521, Cincinnati, $\mathrm{OH}$ 45267-0521, USA

${ }^{\dagger}$ Correspondence.

Revised manuscript received 18 June 1997.
}

compared with those of Yorkshire conceptuses. However, previous studies have focused on differences between litters, and specific comparisons between similarly sized conceptuses have not been examined across days. Further characterization of the differences in development between Meishan and Yorkshire conceptuses may provide insight into the cellular and biochemical mechanisms responsible for differences in reproductive efficiency

The establishment of an exchange of signals between the developing conceptus and the changing maternal uterine environment is critical for embryonic survival and the maintenance of pregnancy (Kraeling ef al., 1975; Bazer and Thatcher, 1977; Zavy et al., 1980; Stone and Seamark, 1985). Oestrogen synthesis in the pig conceptus is believed to be the signal for maternal recognition of pregnancy between days 12 and 13 after mating. Furthermore, the production of oestrogen is believed to influence the uterine environment (Geisert et al., 1982), which in turn has been shown to have a significant impact on the development of the pig conceptus (Youngs $e t$ al., 1994). Oestrogen synthesis is dependent on the activity of two key microsomal enzymes. Cytochrome P450 17 $\alpha$-hydroxylase 
(P450c17) catalyses the synthesis of androgens that are the substrates for cytochrome P450 aromatase (P450arom), the enzyme responsible for oestrogen synthesis. The synthesis of oestrogen by the pig conceptus, which was first demonstrated by Perry et al. (1973), was subsequently shown to increase transiently between days 10.5 and 13 of gestation (Fisher et al., 1985). The amounts of protein and transcripts encoding both P450c17 and P450arom are positively correlated with conceptus oestradiol concentrations (Conley et al., 1992). Several studies have reported that these enzymes are localized to the extraembryonic layers of the preattachment conceptus (Conley et al., 1994; Ko et al., 1994). Therefore, the initiation of gene expression of P450c17 and P450arom, as well as the concentrations of these enzymes, may be an important indication of the differentiation of the extraembryonic membranes (Conley et al., 1994). To date, no study has been conducted to compare the relative amounts of P450c17 and P450arom in the developing conceptus of these two breeds of pigs, and our previous study (Anderson et al., 1993) examined only oestradiol content on day 11.

Consequently, we hypothesized that the lower oestrogen content of Meishan compared with Yorkshire conceptuses results from differences in trophoblast differentiation and would be reflected in the expression of these two steroidogenic enzymes. This hypothesis was addressed by comparing the ontogeny and expression P450c17 and P450arom in individual Meishan and Yorkshire conceptuses of similar blastocyst diameter from day 10.5 to day 14.0 of gestation.

\section{Materials and Methods}

\section{Collection of embryos}

Meishan $(n=21)$ and Yorkshire $(n=20)$ gilts (four to seven postpubertal oestrous cycles) were checked twice daily and hand-mated to a boar of the same breed at the onset of oestrus (day 0 ) and again $24 \mathrm{~h}$ later. Conceptuses were flushed from the uteri of gilts on days 10.5, 11.0, 11.5 or 12.0 of gestation as described by Youngs et al. (1994). The diameter of each conceptus was determined with a metal ruler. On day 14 of gestation, uteri were recovered at slaughter, placed on ice and transported to the laboratory within $30 \mathrm{~min}$. Uteri were dissected free of the mesometrium, bisected at the junction of the uterine body and submerged in a long pan containing physiological saline. Each horn was opened longitudinally along the mesometrial border and individual, elongated conceptuses identified, measured and removed. Each litter was divided into three groups, each represented by conceptuses with an equal range of diameters. DNA, protein and oestradiol assays were performed on one group of conceptuses from each litter ( $n=50$ Yorkshire, 60 Meishan). The second group of conceptuses from each litter was subjected to western immunoblot analysis ( $n=70$ Yorkshires, $n=66$ Meishans). The remaining conceptuses were immediately fixed in $4 \%$ paraformaldehyde and embedded in paraffin wax for use in a subsequent study. Conceptuses were examined individually in all analyses.

Conceptuses assigned to DNA, protein and oestradiol determination were individually pelleted by centrifugation at $4000 \mathrm{~g}$ for $5 \mathrm{~min}$. After removing the excess fluid, conceptuses were lyophilized and resuspended in $1 \mathrm{ml}$ high salt buffer (PBS with

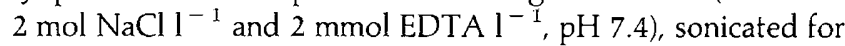
$30 \mathrm{~s}$ and frozen at $-80^{\circ} \mathrm{C}$. Individual conceptuses from a litter assigned to western immunoblot analysis were also centrifuged and frozen at $-80^{\circ} \mathrm{C}$ until analysed.

\section{DNA, protein and oestradiol content}

Conceptus DNA content was determined using the method of Labarca and Paigen (1980) with modifications as reported by Pusateri et al. (1990). Calf thymus DNA was used to generate a standard curve and several aliquots of a pool of pig splenocytes were included in each assay to estimate variation. Fluorescence was measured at both excitation $(356 \mathrm{~nm})$ and emission $(458 \mathrm{~nm}$ ) wavelengths in a Spex fluorimeter. The sensitivity of the assay was $0.005 \mathrm{mg}^{\mathrm{DNA}} \mathrm{ml}^{-1}$. The interand intra-assay coefficients of variance $(\mathrm{CV})$ were $6.1 \%$ and $3.2 \%$, respectively. Protein content in conceptus tissue was determined using Coomassie Brilliant Blue G-250 according to the manufacturers specifications (Bio-Rad Protein Assay, BioRad Chemical Division, Richmond, CA). The standard curve consisted of serial dilutions of BSA at 8.0, 6.0, 4.0, 2.0, 1.0, 0.5, 0.3 and $0.0 \mathrm{mg} \mathrm{ml}^{-1}$. The sensitivity of the assay was $1.0 \mathrm{mg}$ protein $\mathrm{ml}^{-1}$. The inter- and intra-assay $\mathrm{CVs}$ were $7.7 \%$ and $6.4 \%$, respectively. Oestradiol concentrations in individual conceptuses were quantified in unextracted samples as reported by Youngs et al. (1993). Precision and accuracy of the assay were determined by addition of 5, 25 and $100 \mathrm{pg}$ of oestradiol to an embryo pool, resulting in recoveries of 5.6, 27.1 and $117.1 \mathrm{pg}$, respectively. The sensitivity of the assay was $2 \mathrm{pg}$ per tube. Multiple aliquots of a pool of conceptuses were included in each assay resulting in intra- and interassay $\mathrm{CVs}$ of $4.5 \%$ and $12.2 \%$, respectively.

\section{Western immunoblot analysis}

Conceptus tissue was sonicated briefly in PBS containing $1 \%(\mathrm{v} / \mathrm{v})$ sodium cholate and $0.1 \%(\mathrm{v} / \mathrm{v})$ sodium dodecyl sulfate (SDS). Homogenates of whole conceptus were subjected to electrophoresis on $8 \%$ SDS-PAGE gels, as described by Conley et al. (1992). Separated proteins were electroblotted onto nitrocellulose membranes and immunoblotted with antisera (1:2000 dilution) raised against pig P450c17 (A. Payne, University of Michigan, Ann Arbor, MI) and an antisera (1:100 dilution) raised against residues 379-398 of the rat P450arom protein (E. Simpson, University of Texas Southwestern Medical Center, Dallas, TX). A chemiluminescent detection system was used as recommended (Amersham, Arlington Heights, IL). An aliquot of neonatal testes tissue $(10 \mu \mathrm{g}$ per lane) was included as a standard on each gel. Intensities of bands were normalized to this standard for comparisons and autoradiograms were quantified by laser densitometry.

\section{Statistical analyses}

Data were analysed using the general linear models (GLM) procedure of SAS (1985) and reported as means \pm SEM. Dependent variables included DNA ( $\mu$ g per embryo), protein ( $\mu \mathrm{g}$ per 
Table 1. Percentage recovery and number of conceptuses recovered, litter size, and mean size of conceptus from Meishan (M) and Yorkshire $(Y)$ gilts at days 10.5-14.0 of pregnancy

\begin{tabular}{lcccccc}
\hline $\begin{array}{l}\text { Day of } \\
\text { pregnancy }\end{array}$ & Breed & $\begin{array}{c}\text { Number of } \\
\text { gilts }\end{array}$ & $\begin{array}{c}\text { Percentage } \\
\text { recovery of } \\
\text { conceptuses }\end{array}$ & $\begin{array}{c}\text { Number of } \\
\text { conceptuses } \\
\text { recovered }\end{array}$ & $\begin{array}{c}\text { Mean } \\
\text { litter } \\
\text { size }\end{array}$ & $\begin{array}{c}\text { Mean size } \\
\text { of conceptuses } \\
\text { (mm) }\end{array}$ \\
\hline 10.5 & $\mathrm{M}$ & 5 & $90.0 \pm 4.5$ & 59 & $11.8 \pm 1.0$ & $1.9 \pm 0.1$ \\
10.5 & $\mathrm{Y}$ & 4 & $85.9 \pm 5.3$ & 60 & $15.0 \pm 1.8$ & $2.2 \pm 0.1$ \\
11.0 & $\mathrm{M}$ & 4 & $86.7 \pm 9.4$ & 49 & $12.3 \pm 1.5$ & $3.0 \pm 0.2$ \\
11.0 & $\mathrm{Y}$ & 5 & $80.9 \pm 3.6$ & 72 & $14.4 \pm 1.7$ & $3.5 \pm 0.2$ \\
11.5 & $\mathrm{M}$ & 4 & $92.5 \pm 4.9$ & 43 & $14.3 \pm 0.7$ & $4.4 \pm 0.1$ \\
11.5 & $\mathrm{Y}$ & 4 & $77.5 \pm 15.9$ & 30 & $15.0 \pm 3.0$ & $4.9 \pm 0.2$ \\
12.0 & $\mathrm{Y}$ & 4 & $70.8 \pm 11.2$ & 43 & $10.8 \pm 1.6$ & $4.9 \pm 0.4$ \\
12.0 & $\mathrm{M}$ & 4 & $94.2 \pm 4.8$ & 31 & $15.5 \pm 1.5$ & $4.4 \pm 0.3$ \\
14.0 & $\mathrm{Y}$ & 3 & $101.3 \pm 9.2$ & 50 & $12.5 \pm 1.7$ & $215.2 \pm 40.6$ \\
14.0 & & $81.4 \pm 12.6$ & 31 & $10.3 \pm 2.2$ & $311.6 \pm 23.3$ \\
\hline
\end{tabular}

M: Meishan; Y: Yorkshire.

embryo), oestradiol content (pg per embryo), P450c17 and P450arom (as a percentage of standard) and were analysed with a model that included breed and day of gestation as main effects and size (diameter, $\mathrm{mm}$; days $10.5-12.0$ or length, $\mathrm{mm}$; day 14) as a covariate. In addition, correlation coefficients were calculated among individual conceptuses. Means were compared using a multiple range test.

\section{Results}

Details of gilts, number of conceptuses and recovery rates are shown (Table 1). Recovery rates of conceptuses were similar between breeds (Meishan 90.3 $\pm 2.7 \%$ versus Yorkshire $83.4 \pm 3.6 \% ; P=0.2$ ) and across days of gestation (Table 1 ). The average ovulation rate and litter size were greater for Yorkshires than Meishans ( $17.6 \pm 0.2$ versus $14.7 \pm 0.1$ corpora lutea, $P<0.01 ; 14.8 \pm 0.9$ versus $12.1 \pm 0.7$ conceptuses per litter respectively; $P<0.02$ ). Yorkshire litters, one from day 11.5 and two from day 12.0, were omitted from further analysis because they had undergone elongation and individual conceptuses were entangled and could not be dissected free. Excluding these three litters, Meishan litters recovered on days 10.5-12.0 comprised conceptuses ranging in size from 1 to $11 \mathrm{~mm}$ and Yorkshire litters ranged from 1 to $8 \mathrm{~mm}$. Comparisons were made for conceptuses that measured $6 \mathrm{~mm}$ or less because there were too few conceptuses of one or the other breed at a particular size greater than $6 \mathrm{~mm}$. Although conceptuses from all day 14 litters were elongated, because of the method of collection they were recovered individually. Analyses were made on conceptuses of similar size and across all days of pregnancy investigated.

The mean diameter of spherical conceptuses analysed on days 10.5-12.0 (Meishan 4.1 $\pm 0.2, n=101$; Yorkshire $4.0 \pm 0.2, n=102)$ and the mean length of elongated conceptuses from day 14 of gestation (Meishan $123.5 \pm 34.8, n=25$; Yorkshire $130.6 \pm 35.9, n=18$ ) did not differ between breeds. Conceptus diameter was positively correlated with day $(r=0.85 ; P<0.01 ; n=203)$ for both breeds. Positive correlations were also detected between size and DNA $(r=0.95$,
Table 2. Oestradiol, DNA and protein content of pig conceptuses at days 10.5-14.0 of gestation

\begin{tabular}{cccc}
\hline & $\begin{array}{c}\text { Oestradiol } \\
\text { (pg per embryo) }\end{array}$ & $\begin{array}{c}\text { DNA } \\
(\mu \mathrm{g} \text { per embryo) }\end{array}$ & $\begin{array}{c}\text { Protein } \\
(\mu \mathrm{g} \text { per embryo) }\end{array}$ \\
\hline Meishan & $\begin{array}{c}377.2 \pm 51.6^{\mathrm{a}} \\
(60)\end{array}$ & $\begin{array}{c}7.03 \pm 1.72^{\mathrm{b}} \\
(61)\end{array}$ & $\begin{array}{c}94.63 \pm 22.07^{\mathrm{c}} \\
(59)\end{array}$ \\
Yorkshire & $\begin{array}{c}559.2 \pm 101.4 \\
(48)\end{array}$ & $\begin{array}{c}9.88 \pm 2.46 \\
(50)\end{array}$ & $\begin{array}{c}125.64 \pm 22.45 \\
(49)\end{array}$ \\
& & &
\end{tabular}

Means \pm SEM within a column differ ${ }^{\mathrm{a}} P<0.08,{ }^{\mathrm{b}} P<0.001$ and ${ }^{\mathrm{C}} P<0.005$

Figures in parentheses are the number of individual conceptuses analysed.

$n=87 ; \quad P<0.01)$ and size and protein $(r=0.91, n=81$; $P<0.01)$ as well as between day and DNA $(r=0.87, n=87$; $P<0.01)$ and day and protein $(r=0.85, n=81 ; P<0.01)$. Despite similarities in diameter and length of conceptuses, DNA $(P<0.01)$ and protein $(P<0.04$, Table 2$)$ contents were significantly greater in Yorkshire than in Meishan conceptuses.

The oestradiol content of conceptuses observed in the present study was consistent with previously reported values (Anderson et al., 1993) and was positively correlated with conceptus diameter $(P<0.01$; Fig. 1a). There were significant effects of day $(P<0.01)$ and a tendency towards a breed effect $(P<0.08$; Table 2$)$ on conceptus oestradiol content; however, no day by breed interaction was observed $(P<0.9)$. Oestradiol content in Meishan conceptuses increased from day 10.5 to day 11.5 and was maintained thereafter up to day 14.0 (Fig. Ib). A similar pattern was observed in Yorkshire conceptuses but at generally higher values than those observed in Meishan conceptuses. Oestradiol content was not different between breeds on day 10.5, but tended to increase more sharply in Yorkshire conceptuses up to day 11.5. Oestradiol content of Meishan conceptuses was significantly greater on day 12.0 than on days 10.5 and 11.0, whereas oestradiol in Yorkshire conceptuses at days 11.5-14.0 was significantly different from values on day 10.5 (Fig. Ib). 

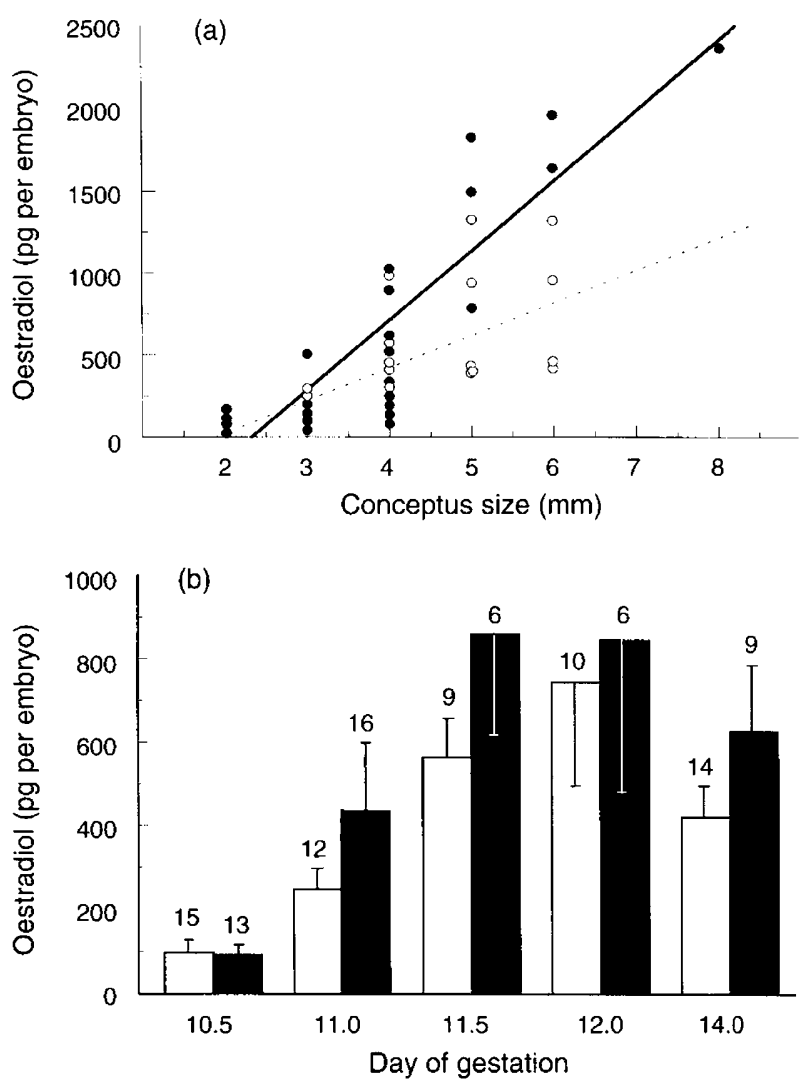

Fig. 1. (a) Linear regression of oestradiol content (pg per embryo) and blastocyst diameter for spherical Meishan (o) or Yorkshire (•) pig conceptuses collected on days 10.5-12.0 of gestation. Meishan: $r=0.72, \quad y=189.16 x-332.77$; Yorkshire: $r=0.78, y=340.99 x-$ 706.48; $P<0.01$. (b) Oestradiol content (pg per embryo) of Meishan $(\square)$ and Yorkshire ( $\square$ ) pig conceptuses collected on days 10.5-14.0 of gestation. Each bar represents the mean \pm SEM.

Western immunoblot analysis was performed on 66 Meishan and 70 Yorkshire conceptuses, ranging in diameter from 2-6 mm (days 10.5-12) to $100-410 \mathrm{~mm}$ (day 14), to examine breed differences in the expression of P450c17 and the pattern of expression during blastocyst development (Fig. 2). Overall, P450c17 expression was positively correlated with conceptus diameter (Fig. 3a). On day 10.5, expression of P450c17 was very low and, in many cases, below the limits of sensitivity of the analysis for both Meishan and Yorkshire conceptuses despite the presence of oestrogen. However, by day I1, expression of P450c17 by Yorkshire conceptuses had already increased above that in Meishans $(P<0.01)$, reaching peak values on day 11.5 and decreasing from day 12.0 to day 14.0 , when values were again similar to those of Meishan conceptuses (Fig. 3b). Eighty-three of the conceptuses analysed for P450c17 (38 Yorkshire, 45 Meishan) were also examined for the expression of P450arom by western immunoblot analysis (Fig. 4). P450arom was positively correlated with conceptus size for Yorkshires but not for Meishans (Fig. 5a). An effect of breed was observed for P450c17 and P450arom (Meishan: $22.71 \pm 4.35,24.93 \pm 10.45$, and Yorkshire: $93.52 \pm 15.24$, $91.50 \pm 21.15 ; P<0.02$, respectively). In addition, when analysed by day, Yorkshires had greater expression of P450arom than Meishans on day 11.5 ( $P<0.05$; Fig. $5 b$ ).

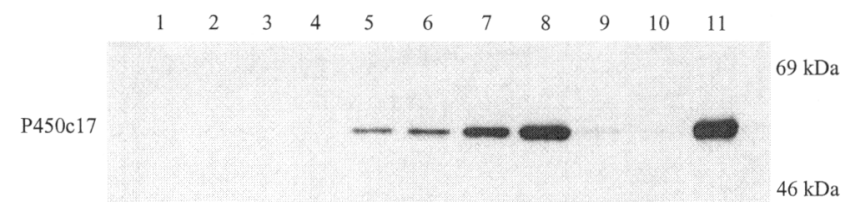

Fig. 2. Representative western immunoblot analysis of Meishan (lanes $1,3,5,7$, and 9) and Yorkshire (lanes 2, 4, 6, 8, and 10) pig conceptuses. Each lane contains $10 \mu \mathrm{g}$ of crude protein from conceptuses collected on days 10.5 (lanes 1 and 2), 11.0 ( 3 and 4), 11.5 (5 and 6), 12.0 ( 7 and 8 ), and 14.0 ( 9 and 10) of gestation. Samples loaded in lanes 1-6 were from individual conceptuses that measured less than $4 \mathrm{~mm}$ in diameter. The diameter of individual Meishan and Yorkshire conceptuses at day 12.0 of gestation from which samples were loaded in lanes 7 and 8 measured $6 \mathrm{~mm}$. The day 14.0 conceptuses from which samples were loaded in lanes 9 and 10 were 35.2 and $35.6 \mathrm{~cm}$ long, respectively. Each western immunoblot included a $10 \mu \mathrm{g}$ sample of homogenized neonatal pig testes as an internal control (lane II). Membranes were immunoblotted using antisera raised against (P450c17), resulting in detection of a single immunoreactive band at the cytochrome P450 17 $\alpha$-hydroxylase expected size of $54 \mathrm{kDa}$.

\section{Discussion}

Although it is widely accepted that oestradiol secretion by pig blastocysts has a critical function in the establishment of pregnancy, as well as in conceptus development, the regulation of oestradiol synthesis by the conceptus is not well understood. There are several points in the steroidogenic pathway at which oestradiol may be regulated. For instance, it is possible that substrate availability, steroid metabolism or the level of enzyme expression could alter the concentrations of steroids (Conley and Mason, 1990). Previous studies from our laboratory have suggested that either P450c17 or P450arom may be rate limiting in oestrogen synthesis by pig conceptuses (Conley et al., 1992). Since Meishan and Yorkshire conceptuses differ in their relative rates of preattachment development, in the present study, we further examined these enzymes in individual conceptuses of each breed at a similar developmental stage.

Pope (1988) hypothesized that one of the major factors affecting the loss of pig conceptuses during early pregnancy was the asynchronous development among individuals within a litter. Furthermore, it was hypothesized that those conceptuses within a litter that are less developed at the time of the oestrogen-induced change in the composition of uterine histotroph are least likely to survive. Anderson et al. (1993) reported that Meishan conceptuses over $6 \mathrm{~mm}$ in diameter contained less oestradiol than did Yorkshire conceptuses. Therefore, it was concluded that a lower rate of oestradiol synthesis by Meishan conceptuses, compared with Yorkshire conceptuses, might induce a less marked change in the uterine environment, resulting in the survival of less-developed littermates and a greater litter size. Our data are consistent with the findings of Anderson et al. (1993), suggesting that Meishan conceptuses $4-6 \mathrm{~mm}$ in diameter tend to contain lower concentrations of oestradiol than those in Yorkshire blastocysts of similar diameter. The present study, however, goes further by examining and comparing the expression of P450c17 and P450arom between these two breeds across several days. Consistent with oestrogen concentrations, the relative expression of P450c17 and P450arom was significantly lower in Meishan 

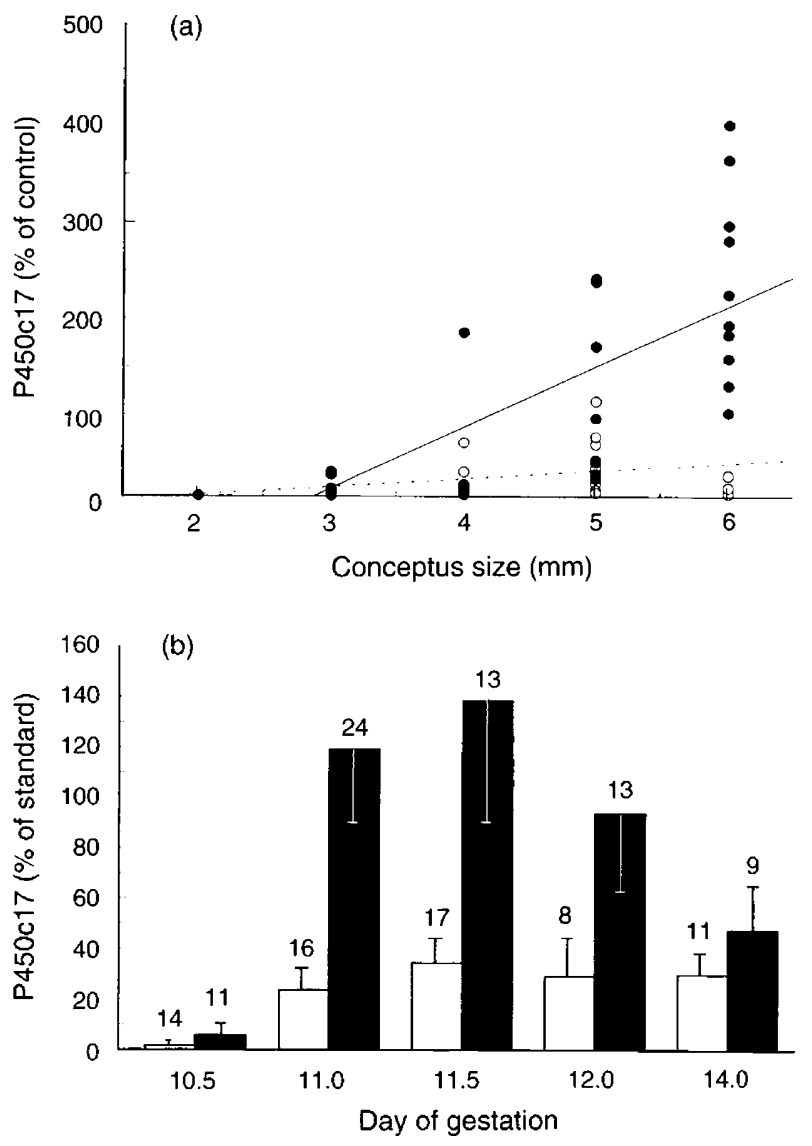

Fig. 3. (a) Linear regression of immunodetectable cytochrome P450 17a-hydroxylase (P450c17) and blastocyst diameter for individual spherical Meishan ( ) or Yorkshire (•) pig conceptuses collected on days 10.5-12.0 of gestation. Meishan: $r=0.37, y=8.68 x-12.97$; Yorkshire: $r=0.71, y=61.67 x-170.30 ; P<0.01$. (b) Expression of P450c17 by Meishan ( $\square$ ) and Yorkshire ( $\square$ ) pig conceptuses collected on days 10.5-14.0 of gestation. Amounts of $\mathrm{P} 450 \mathrm{c} 17$ were determined by western immunoblot analyses and laser densitometry. Bars represent the means \pm SEM which were calculated after each immunoreactive band was normalized to the standard, $10 \mu \mathrm{g}$ of protein from homogenized neonatal pig testes, included as a sample on each gel.

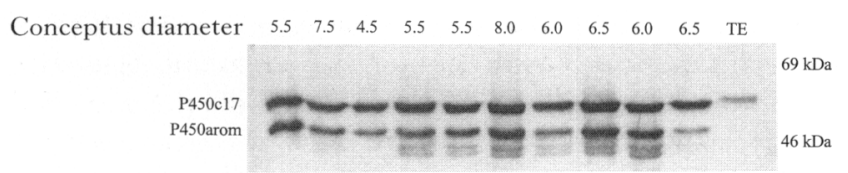

Fig. 4. Western immunoblot analyses of individual Yorkshire pig littermate conceptuses recovered on day 12 of gestation. Individual conceptuses, ranging in diameter from 4.5 to $8.0 \mathrm{~mm}$, were homogenized and the entire sample loaded for analysis. Membranes were immunoblotted independently and sequentially with antisera raised against pig cytochromes $\mathrm{P} 450$ 17a-hydroxylase (P450c17) and aromatase ( $\mathrm{P} 450$ arom) resulting in the appearance of two immunoreactive bands of expected size ( $54 \mathrm{kDa}$ and $48 \mathrm{kDa}$, respectively). TE: testis (10 $\mu \mathrm{g})$.

conceptuses than in Yorkshire conceptuses from day 10.5 to day 14.0. The constraint imposed by comparing blastocysts of equal diameter on the same day of gestation necessitated that
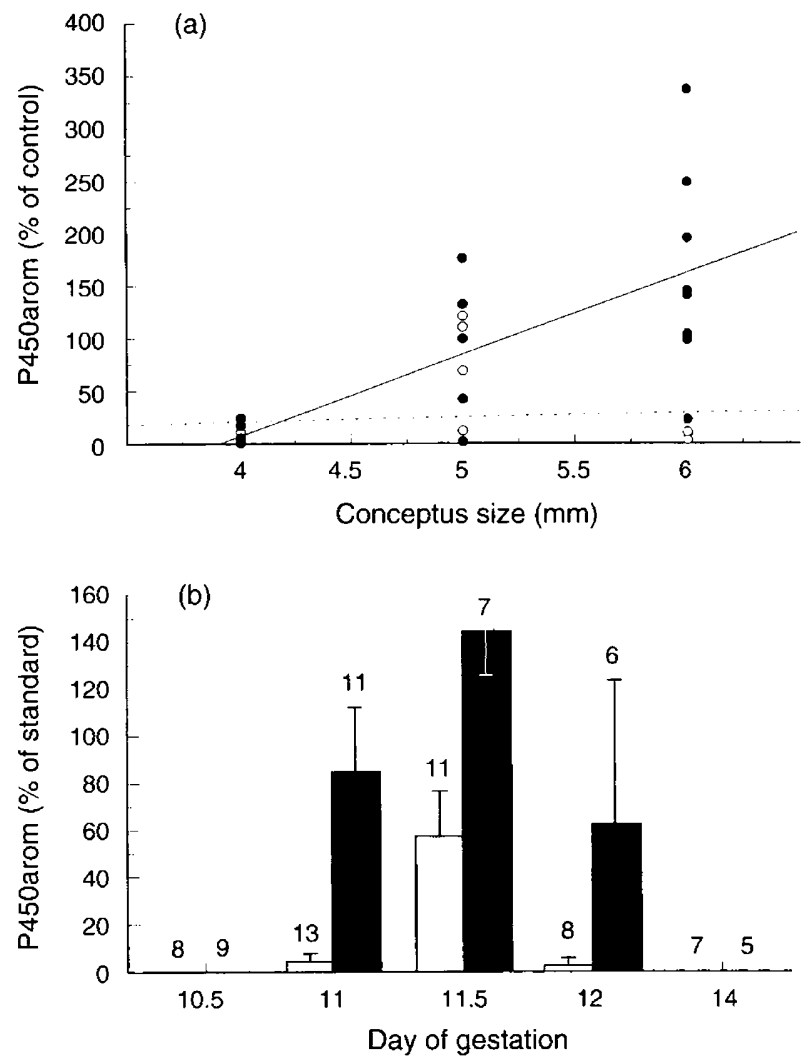

Fig. 5. (a) Regression analysis of immunodetectable cytochrome P450 aromatase (P450arom) and blastocyst diameter for individual spherical Meishan ( $)$ or Yorkshire ( $\bullet$ pig conceptuses collected on days 10.5-12.0 of gestation. Meishan: $r=0.04, y=2.11 x-14.48$; Yorkshire: $r=0.74, y=82.07 x-322.56 ; P<0.01$. (b) Mean P450arom expression detected by western immunoblot analysis in Meishan $(\square)$ and Yorkshire $(\boldsymbol{\square})$ pig conceptuses collected on days 11.0, 11.5, and 12.0 of gestation. Bars represent the means \pm SEM calculated using densitometry after each immunoreactive band was normalized to the standard, $10 \mu \mathrm{g}$ of protein from neonatal pig testes, included on each gel.

conceptuses were examined when enzyme expression was low relative to later stages of development. The observed differences in both conceptus oestradiol content and enzyme activities may have been even greater had there not been these constraints.

Preattachment pig conceptuses have been shown to express several steroidogenic enzymes, specifically side-chain cleavage cytochrome P450 (P450scc), P450c17 and P450arom (Conley et al., 1992; Ko et al., 1994; Green et al., 1995; Strömstedt et al., 1996). The results of these studies suggest that the ontogeny of $\mathrm{P} 450 \mathrm{c} 17$ expression is delayed in early developing blastocysts compared with that of P450scc and P450arom. Furthermore, they demonstrated a marked reduction in P450c17 expression, a smaller reduction in P450arom but no reduction in P450scc expression, after conceptus elongation that was coincident with the marked decrease in oestrogen content in the conceptus. On the basis of these observations, it was suggested that P450c17 might be the rate-limiting enzyme in the production of oestradiol by the pig conceptus (Conley et al., 1992). The results for the Yorkshire conceptuses from the 
present experiment are consistent with previous data (Conley et al., 1992; Green ef al., 1995) demonstrating that P450c17 expression is detectable in conceptuses greater than $4 \mathrm{~mm}$ in diameter but markedly lower in elongated conceptuses at day 14 of gestation. However, the increrase in expression of P450c17 was not as great in Meishan as it was in Yorkshire conceptuses despite increases in oestradiol content of conceptuses. Nor was there a significant fall in the expression of P450c17 at day 14 in Meishans. These differences in blastocyst expression of P450c17 suggest that there is a fundamental difference in the physiology of the Meishan and Yorkshire trophoblast. Moreover, these data indicate that, in Yorkshire conceptuses at least, increased expression of P450c17 and P450arom occurs between days 11 and 12 of gestation regardless of conceptus diameter. In other words, trophoblastic differentiation is effected on these days across the litter as a whole, is not necessarily associated with an increase in conceptus size, and therefore, is not solely dependent on intrinsic development mechanisms.

It is well established that the synthesis of oestrogen by the pig conceptus is coincident with its marked elongation between day 12 and day 13 of gestation (Dhindsa and Dziuk, 1968; van der Meulen et al., 1988). The process of elongation involves the reorganization of the trophoblast (Geisert et al., 1982) and this cell layer is believed to be the site of oestrogen synthesis (King and Ackerley, 1985; Bate and King, 1988). A distinct pattern of regionalized expression has been shown to exist for P450c17 and P450arom in the developing pig conceptus. Specifically, Conley et al. (1994) observed that both P450c17 and P450arom were expressed in the trophoblast of the preattachment conceptus. Interestingly, the trophoblast appears to be the only germ layer in which P450c17 is expressed. Besides being the only cell layer expressing P450c17, the trophoblast also comprises the majority of the cells at the blastocyst stage (Heuser and Streeter, 1929). Furthermore, consistent with the present data, it has been shown that Meishan blastocysts contain fewer cells than do Yorkshire blastocysts on day 11-12 of gestation (Anderson et al., 1993) and this difference may be due primarily to reduced numbers of trophoblast cells based on studies conducted on blastocysts before hatching (Rivera et al., 1996). Therefore, the fact that P450c17 is localized specifically to the trophoblast indicates that the size of the trophoblast may be responsible in part for the differences observed in the expression of P450c17 between Meishan and Yorkshire conceptuses.

As mentioned above, the expression of P450arom has been localized to the trophoblast of the developing conceptus. However, unlike P450c17, P450arom has also been shown to be present in the endoderm (Ko et al., 1994) and, more specifically, regionalized to the hypoblast (Conley et al., 1994). Although expression of P450arom is not confined to a single germ layer, a similar explanation, as for $\mathrm{P} 450 \mathrm{c} 17$, may pertain to the differences observed in expression of P450arom by Meishan and Yorkshire conceptuses As the blastocyst expands, the cells that form the endoderm begin to protrude from the inner cell mass, forming a second complete cell layer inside the original trophoblast layer. The endoderm only grows as large as the encompassing trophoblast will allow. A larger trophoblastic diameter allows for a greater endodermal diameter and as a result a greater expression of P450arom in Yorkshire conceptuses. Therefore, as with P450c17, the P450arom expression may, in part, be dictated by the size of the germ layer in which it is expressed.

The uterine environment also plays a significant role in the development of the early pig conceptus. In reciprocal embryo transfer experiments, Youngs et al. (1994) established that the uterine environment of the Meishan exhibited a suppressive effect on the growth and development of Yorkshire conceptuses while the Yorkshire uterine environment had a beneficial effect on transferred Meishan conceptuses. Interestingly, it was reported that individual Meishan conceptuses allowed to develop in a Yorkshire uterus had greater oestradiol per microgram of DNA than conceptuses from the other three transfer groups. In the light of this report, and in conjunction with the data of the present study with respect to enzyme expression, it is possible that the uterus regulates the production of conceptus oestrogens by modifying the expression of steroidogenic enzyme or substrate availability. A change in the uterine environment has been demonstrated at about day 12 of gestation (Geisert et al., 1982). This change is associated with an increased synthesis of oestradiol by the conceptus and an increase in the synthesis of uterine insulin-like growth factor I (IGF-I) (Tavakkol et al., 1988; Simmen et al., 1990). IGF-I may be a regulator of oestradiol synthesis in the ovary (Erickson et al., 1989; Mondschein et al., 1989) and placenta (Nestler, 1989), as well as a mitogen, in both the uterus (Simmen et al., 1988) and conceptus (Harvey and Kaye, 1992). Hofig et al. (1991) observed a stimulatory effect of IGF-I on aromatase activity in pig conceptuses at day 12 in vitro. Furthermore, both IGF-I and IGF-I receptor transcripts were shown to be constitutively expressed in spherical and elongated conceptuses across several days of early pregnancy (Green et al., 1995). The presence of receptors for IGF-I in the chorion (Corps et al., 1990) and increased concentrations of uterine IGF-I (Letcher et al., 1989) suggest a possible maternal-fetal interaction whereby oestradiol synthesis by the conceptus may be regulated, ultimately influencing conceptus survival. However, this role for IGF-I does not rule out the effects of other uterine- or conceptus-derived factors.

In summary, the present study provides new insight into an understanding of the developmental differences between Meishan and Yorkshire conceptuses. These data show a unique pattern of P450c17 expression in the preattachment Meishan conceptus compared with that of the Yorkshire conceptus, suggesting a fundamental difference in the development and differentiation of the trophoblast of these two breeds.

This work was funded by a grant from the United States Department of Agriculture 93-37206-1299 to A. J. Conley. The authors wish to thank C. J. Corbin, C. Hertz, R. Rivera, and M. Wilson for their technical assistance.

\section{References}

Anderson LH, Christenson LK, Christenson RK and Ford SP (1993) Investigations into the control of litter size in swine. II. Comparisons of morphological and functional embryonic diversity between Chinese and American breeds Journal of Animal Science 71 1566-1571

Bate LA and King GJ (1988) Production of oestrone and oestradiol-17 $\beta$ by different regions of the filamentous pig blastocyst Journal of Reproduction and Fertility 84 163-169 
Bazer FW and Thatcher WW (1977) Theory of maternal recognition of pregnancy in swine based on estrogen controlled endocrine versus exocrine secretion of prostaglandin $\mathrm{F}_{2 \alpha}$ by uterine endometrium Prostaglandins 14 $397-401$

Bazer FW, Thatcher WW, Martinat-Botte F and Terqui M (1988) Conceptus development in Large White and prolific Chinese Meishan pigs Journal of Reproduction and Fertility $\mathbf{8 4} 37-42$

Bolet G, Martin-Botte F, Locateiil A, Gruand J, Terqui M and Berthelot F (1986) Components of prolificacy in hyperprolific Large White sows compared with the Meishan and Large White breeds Genetic Selection and Evolution 18 333-342

Cheng P (1983) A highly prolific pig breed of China - the Taihu Pig Pig News and Information 4 407-416

Conley AJ and Mason JI (1990) Placental steroid hormones Clinical Endocrinology and Metabolism 4 249-272

Conley AJ, Christenson RK, Ford SP, Geisert RD and Mason JI (1992) Steroidogenic enzyme expression in pig conceptuses during and after elongation Endocrinology 131 896-902

Conley AJ, Christenson LK, Ford SP and Christenson RK (1994) Immunocytochemical localization of cytochromes $\mathrm{P} 450$ 17 $\alpha$-hydroxylase and aromatase in embryonic cell layers of elongating porcine blastocysts Endocrinology 135 $2248-2254$

Corps AN, Brigstock DR, Littlewood CJ and Brown KD (1990) Receptors for epidermal growth factor and insulin-like growth factor- 1 on preimplantation trophoderm of the pig Development 110 221-227

Dhindsa DS and Dziuk PJ (1968) Effect of pregnancy in the pig after killing embryos or fetuses in one uterine horn in early gestation Journal of Animal Science 27 122-126

Erickson GF, Garzo VG and Magoffin DA (1989) Insulin-like growth factor-I regulates aromatase activity in human granulosa and granulosa luteal cells Journal of Clinical Endocrinology and Metabolism 69 716-724

Fisher HE, Bazer FW and Fields MJ (1985) Steroid metabolism by endometrial and conceptus tissues during early pregnancy and pseudopregnancy in gilts Journal of Reproduction and Fertility 75 69-78

Geisert RD, Thatcher WW, Roberts RM and Bazer FW (1982) Establishment of pregnancy in the pig. III. Endometrial secretory response to estradiol valerate administered on day II of the estrous cycle Biology of Reproduction 27 957-965

Green ML, Simmen RCM and Simmen FA (1995) Developmental regulation of steroidogenic enzyme gene expression in the perimplantation porcine conceptus: a paracrine role for insulin-like growth factor-1 Endocrinology 136 3961-3970

Haley CS, Ashworth CJ, Lee GJ, Wilmut I, Aitkin RP and Ritchie W (1990) British studies of the genetics of prolificacy in the Meishan pig. In Proceedings EAAP Chinese Pig Symposia pp 83-97. Toulouse, France

Harvey MB and Kaye PL (1992) Insulin-like growth factor-1 stimulates growth of mouse preimplantation embryos in vitro. Molecular Reproduction and Development 31 195-199

Heuser CH and Streeter GL (1929) Early stages in the development of pig embryos, from the period of initial cleavage to the time of the appearance of limb-buds Contributions to Embryology 20 1-29

Hofig A, Simmen FA, Bazer FW and Simmen RCM (1991) Effects of insulin-like growth factor-I on aromatase cytochrome $\mathrm{P} 450$ activity and oestradiol biosynthesis in preimplantation porcine conceptuses in vitro. Journal of Endocrinology 130 245-250

King GJ and Ackerley CA (1985) Demonstration of oestrogens in developing pig trophoblast and yolk sac endoderm between days 10 and 16 Journal of Reproduction and Fertility 73 361-367

Ko Y, Choi I, Green ML, Simmen FA and Simmen RCM (1994) Transient expression of the cytochrome $\mathrm{P} 450$ aromatase gene in elongating porcine blastocysts is correlated with uterine insulin-like growth factor levels during peri-implantation development Molecular Reproduction and Development 37 $1-11$
Kraeling RR, Barb CR and Davis BJ (1975) Prostaglandin-induced regression of porcine corpora lutea maintained by estrogen Prostaglandins 9 459-462

Labarca $C$ and Paigen K (1980) A simple, rapid and sensitive DNA assay procedure Analytical Biochemistry 102 344-352

Letcher R, Simmen RCM, Bazer FW and Simmen FA (1989) Insulin-like growth factor- 1 expression during early conceptus development in the pig Biology of Reproduction 41 1143-1151

Mondschein JS, Canning SF, Miller DQ and Hammond JM (1989) Insulin-like growth factors (IGFs) as autocrine/paracrine regulators of granulosa cell differentiation and growth: studies with a neutralizing monoclonal antibody to IGF-I Biology of Reproduction 40 79-85

Nestler JE (1989) Insulin and insulin-like growth factor-I stimulate the $3 \beta$-hydroxysteroid dehydrogenase activity of human placental cytotrophoblasts Endocrinology 125 2127-2133

Perry IS, Heap RB and Amoroso EC (1973) Steroid hormone production by pig blastocysts Nature 245 45-47

Pope WF (1988) Uterine asynchrony: a cause of embryonic loss Biology of Reproduction 39 999-1003

Pusateri AE, Rothschild MF, Warner CM and Ford SP (1990) Changes in morphology, cell size and cellular estrogen content of individual littermate pig conceptuses on days 9 to 13 of gestation Journal of Animal Science 68 $3727-3735$

Rivera RM, Youngs CR and Ford SP (1996) A comparison of the number of inner cell mass and trophoblast cells of preimplantation Meishan and Yorkshire pig embryos at similar developmental stages Journal of Reproduction and Fertility $106111-116$

Simmen RCM, Ko Y, Liu XH, Wilde MH, Pope WF and Simmen FA (1988) A uterine cell mitogen distinct from epidermal growth factor in porcine uterine luminal fluids: characterization and partial purification Biology of Reproduction $38551-561$

Simmen RCM, Simmen FA, Hofig A, Farmer SJ and Bazer FW (1990) Hormonal regulation of insulin-like growth factor gene expression Endocrinology 127 $2166-2174$

Statistical Analysis Systems Institute Inc. (1985) User's Guide; Statistics. SAS Institute Inc., Cary, NC

Strömstedt M, Keeney DS, Waterman MR, Paria BC, Conley AJ and Dey SK (1996) Preimplantation mouse blastocysts fail to express CYP genes required for estrogen biosynthesis Molecular Reproduction and Development 43428 436

Stone BA and Seamark RF (1985) Steroid hormones in uterine washings and in plasma of gilts between days 9 and 15 after oestrus and between days 9 and 15 after coitus Joumal of Reproduction and Fertility 75 209-221.

Tavakkol A, Simmen FA and Simmen RCM (1988) Porcine insulin-like growth factor-I (pIGF-I): complementary deoxyribonucleic acid cloning and uterine expression of messenger ribonucleic acid encoding evolutionarily conserved IGF-I peptides Molecular Endocrinology 2 674-681

van der Meulen J, Helmond FA and Oudenaarden CPJ (1988) Effect of flushing of blastocysts on days $10-13$ on the lifespan of the corpora lutea in the pig Journal of Reproduction and Fertility 84 157-162

Youngs CR, Ford SP, McGinnis LK and Anderson LH (1993) Investigations into the control of litter size in swine. I. Comparative studies on in vitro development of Meishan and Yorkshire preimplantation embryos Journal of Animal Science 71 1561-1565

Youngs CR, Christenson LK and Ford SP (1994) Investigations into the control of litter size in swine. III. A reciprocal embryo transfer study of early conceptus development Journal of Animal Science 72 725-731

Zavy MT, Bazer FW, Thatcher WW and Wilcox CJ (1980) A study of prostaglandin $\mathrm{F}_{2 u}$ as the luteolysin in swine. V. Comparison of prostaglandin F, progestins, estrone and estradiol in uterine flushings from pregnant and non-pregnant gilts Prostaglandins 20 837-851 